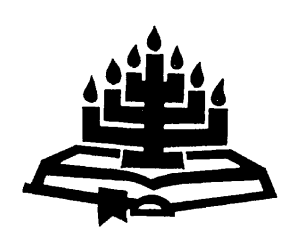

\title{
Die kerk en geregtigheid in die Matteusevangelie
}

\author{
F.P. Viljoen \\ Skool vir Bybelwetenskappe \& Antieke Tale \\ Noordwes-Universiteit \\ Potchefstroomkampus \\ POTCHEFSTROOM \\ E-pos: Viljoen.Francois@nwu.ac.za
}

\begin{abstract}
The church and righteousness in the Matthean gospel

In his academic and ecclesiastical work Prof. A. le R. du Plooy constantly urged that church polity should be executed in such a manner that the church is built intensively and extensively. As a tribute to this respected colleague I examine the teaching in Matthew's Gospel (frequently called the ecclesiastical Gospel) on the nature and functioning of the church and how it should execute righteousness. I indicate how Du Plooy's approach to church polity complies with the first Gospel's teaching on the church and righteousness. I argue that a better understanding of Matthew's teaching will enrich the current church in its practice of righteousness.
\end{abstract}

\section{Opsomming}

\section{Die kerk en geregtigheid in die Matteusevangelie}

In sy akademiese en kerklike werk het prof. A. le R. du Plooy deurgaans daarop aangedring dat kerkreg beoefen moet word op so 'n manier dat die kerk intensief en ekstensief opgebou word. As huldeblyk aan hierdie gerespekteerde kollega ondersoek ek die onderrig van die Matteusevangelie (dikwels die ekklesiastiese Evangelie genoem) oor die aard en funksie van die kerk en hoe geregtigheid moet geskied. Ek toon aan hoedat Du Plooy se benadering tot kerkreg by die eerste Evangelie se onderrig van kerk en geregtigheid aansluit. Ek voer aan dat 'n beter begrip vir Matteus se onderrig die kerk in haar uitoefening van reg sal verryk. 


\section{Inleiding}

Prof. A. le R. du Plooy het vanweë sy akademiese en kerklike werk 'n gewaardeerde nasionale en internasionale profiel opgebou. Die konstruktiewe en ireniese manier waarop hy kerkreg in die akademie en kerke geleer en toegepas het, verdien besondere vermelding. Benewens die onderrig wat hy in die klaskamers gegee het, asook konstruktiewe leiding en advies op kerklike terrein, blyk sy opbouende benadering tot die Kerkreg uit sy publikasies. Du Plooy spreek hom telkens daaroor uit dat kerkreg tot die aedificatio ecclesiae moet dien (cf. Du Plooy, 1998:53). Hy keur die tendens af om kerkreg bloot te assosieer met die formele toepassing van reëls en regulasies, terwyl die opbou van die kerk aan die praktiese teologie oorgelaat word (Du Plooy, 1995:139). Met verwysing na Matteus 16:17-19 en 18:17 sluit hy by Calvyn aan as hy argumenteer dat die potestas van die kerk "is to build up the church, not to destroy it" (Du Plooy, 1998:55). Hierdie opbou behels 'n ekstensiewe (na buite gerigte) sowel is ' $n$ intensiewe (na binne gerigte) aktiwiteit. Oor die toepassing van kerkregtelike beginsels, beredeneer hy hoe belangrik ' $n$ suiwer kerkbegrip is (Du Plooy, 1998:62). Christus is die Hoof van die kerk. Hý dra die sleutels van die koninkryk. Die plaaslike kerk en meerdere vergaderings het die verantwoordelikheid en jurisdiksie om die gesag van Christus te bedien (Du Plooy, 1998:65). Kerkreg is sui generis, omdat die kerk 'n unieke aard het (Du Plooy, 1995: 139). Kerkreg moet in die Heilige Skrif gewortel bly.

Die doel van kerkreg is ... om uit die Skrif na te vors hoe Christus deur die bediening van die sleutels van die koninkryk tot in die harte van sy kinders kan deurdring, sodat die kerk waarlik die liggaam van Christus kan wees. (Du Plooy, 1995:144.)

Die koninkryk van God dui op die dinamiese regering van God in en deur Jesus Christus. Christus openbaar in sy Woord wat reg is.

Christus is die Wetgewer, en die kerk word deur sy Gees en Woord geleer wat die gedrag in leer en lewe, en die orde in die kerk moet wees. God se reg hou direk verband met die liefde, die genade en oordeel, en met die wil van God. (Du Plooy, 1995:152.)

Dit gaan vir Christus veral daarom om sy uitverkore kinders deur die bediening van die Woord en Gees as kerk te vergader ten einde hulle in die koninkryk van die hemel te laat ingaan. Wie kerkreg beoefen, moet altyd met hierdie beginsel rekening hou. "Kerkreg moet 
lei tot 'n kerkregering wat soos 'n kanaal 'n deurgang vir die ware leer tot opbou van die kerk bied." (Du Plooy, 1995:156.)

Dit is duidelik dat Du Plooy baie klem lê op die wese van die kerk en veral hoe dit in die Matteustekste aan die orde kom, asook dit wat as reg vir die kerk bedoel word. 'n Nadere verklaring van wat Matteus spesifiek met die "kerk" en "reg" bedoel, behoort verdere toeligting te bied op Du Plooy se benadering. Die gevaar bestaan dat hedendaagse teoloë terme van 'n antieke teks anakronisties en buite konteks intepreteer in die lig van hoe so 'n term later deur die loop van die tyd ontwikkel het. In hierdie artikel word gefokus op die twee sleutelterme, kerk en reg (geregtigheid), wat dikwels in kerkregtelike argumente aan die orde kom, en soos dit in die Matteusevangelie gebruik word. Soos uit hierdie ondersoek blyk, heg Matteus 'n besondere konnotasie aan die terme kerk en reg wat 'n bepalende invloed op kerkregtelike beginsels het wat uit die Matteusevangelie afgelei word.

In Matteus moet hierdie terme in die lig van die koms van die koninkryk geïnterpreteer word (Viljoen, 2007a:303). Die uitdrukking "die evangelie van die Koninkryk" (t 0 ; eujggetion th $\sim$ bas il eil $\sim$ ) is uniek aan Matteus (Matt. 4:23; 9:35; 24:14). Met die koms van die koninkryk het 'n nuwe eskatologiese gemeenskap (ekkl hsia) tot stand gekom en hulle word opgeroep tot 'n nuwe vorm van ge-

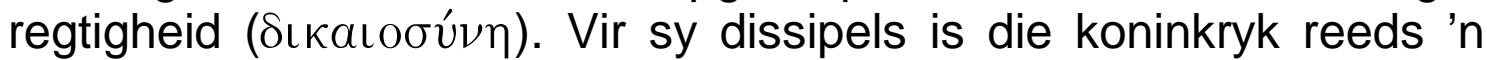
realiteit (vgl. Matt. 5:3 en 10), maar daar is ook 'n verwagting van 'n toekomstige voller manifestasie daarvan (vgl. Matt. 13:31-33, 4446). In hierdie artikel word gepoog om groter duidelikheid te bied oor wat geregtigheid vir die volgelinge van Jesus in die Matteusgemeenskap beteken het en om daaruit gevolgtrekkings vir die kerk van vandag af te lei.

\section{Die kerk in Matteus}

Matteus word dikwels die ekklesiologiese Evangelie genoem. Bornkamm (1963:38) skryf:

No other gospel is so shaped by the thought of the Church as Matthew's, so constructed for use by the Church; for this reason it has exercised, as no other, a normative influence on the later Church.

Johnson (1986:172) skryf: "Matthew is the gospel of the church". Matteus is die enigste Evangelie wat die selfstandige naamwoord 
ekkI hs i (Matt. 16:18; 18:17) ${ }^{1}$ bevat. Matteus is ook die Evangelie wat die aard en funksionering van hierdie geloofsgemeenskap in meer besonderhede beskryf (Martin, 1975:42).

Die Matteusevangelie moet as transparante verhaal gelees word (Luz, 2005:17). Die Evangelie funksioneer op twee vlakke. Toegespits op die wese van die kerk, verhaal die Evangelie op die boonste vlak die lewe van Jesus en sy eerste volgelinge, terwyl dit op 'n volgende vlak ook iets van die latere Matteusgemeenskap vertel (Saldarini, 1991:39). In die Evangelies vind 'n leser wel minder inligting oor die plaaslike gemeente waarbinne die teks ontstaan het as wat die geval is in die briewe van die Nuwe Testament (Bauckham, 1998:48). Nogtans is die Evangelies binne bepaalde omstandighede geskryf. Plaaslike situasies en vraagstukke is herkenbaar, hoewel in 'n mindere mate (cf. Carter, 2000:7; Klijn, 1968:45). Aldus kan die Sitz im Leben der alten Kirche op 'n indirekte manier in die teks herken word (White, 1991:212). Die verhaal van Jesus en sy dissiples sluit die verhaal van die geloofsgemeenskap waarbinne die Evangelie ontstaan het, in. Donaldson (1985:18) skryf:

The evangelists were authors and theologians in their own right, who, living in the midst of concrete and (at least potentially) identifiable church situations, shaped the Gospel traditions as they received them in order to address particular issues and needs which were present in those church situations ... the community not only transmits the Gospel tradition, but provides the setting in which and for which the tradition is shaped and interpreted.

Matteus vertel die verhaal van groeiende weerstand van die Joodse gemeenskap teenoor Jesus en sy dissipels, van 'n afskeiding en die oorwinning van Jesus teenoor sy teenstanders (Overman, 1990:35). Jesus is deur die Joodse leiers en die volk verwerp (Matt. 23:34-39; 27:24-25). Die gevolg is dat die Israeliete, wat Jesus as Messias verwerp, ophou om die volk van die belofte te wees (Matt. 21:43) en dat die nuutgevormde kerk hulle bevoorregte posisie oorneem (Hagner, 2008:173). Mense wat Jesus verwerp, sal onder God se oordeel kom (vgl. Matt. 24:1-2). Matteus beskryf die sinagoges as plekke van skynheiligheid en die Joodse godsdienstige leiers as skynheiliges (Carter, 2000:5).

1 Ekklhsi was 'n term wat bekend was onder die Griekssprekende Jode, aangesien dit die LXX-vertaling was van qahal, die "samekoms van die volk van God" (France, 1998:211). 
lets van die spanning wat die Matteusgemeenskap beleef het, word in hierdie verhaal weerspieël (Viljoen, 2007b:702). Die Joodse Christene is uit die sinagoges verban soos blyk uit die feit dat Matteus van "hulle" en "julle" sinagoges praat (Matt. 4:23; 9:35; 10:17; ens.). Reuther (1974:30) beskryf dit as 'n "family conflict" wat verband hou met "rival claims to exclusive truth within the same religious symbol system". Hummel (1966:55) praat selfs van 'n wedywering tussen feindliche Brüder oor die waarheid. Hierdie "familie konflik" moet nader verklaar word. In die tyd van Jesus het strydende Joodse sektes met mekaar gewedywer om hulleself as die eintlike oorblyfsel van Israel te definieer. Onder hierdie sektes het die Esseners, die Fariseërs, Sadduseërs, Selote en verskeie ander apokaliptiese groepe getel. Te midde van hierdie intra-Joodse konflik het Joodse sektes om selfhandhawing gekompeteer. Die gevolg is dat ook die sogenaamde "Jesus-beweging" ingetrek is in die stryd tussen die Joodse godsdienstige groepe. Die Joodse Christene het hulleself van die ander Judaïstiese bewegings onderskei (Saldarini, 1991:49). Luz (2001:255) toon oortuigend aan dat die konflik tussen Matteus en die destydse Judaïsme nie beskou moet word as 'n moeder-dogter konflik nie, maar eerder as "rival between siblings". Matteus se polemiek is nie teen die Jodendom in die algemeen gemik nie, maar teen bepaalde interpretasies binne die Judaïstiese bewegings en hulle opponerende leiers (Saldarini, 1994:44). AntiJudaïstiese argumente het daarom ' $n$ wesenlike rol gespeel in die selfdefiniëring van die Christelike gemeenskap in die krisis van afskeiding en oorgang. Spesifieke sosio-historiese oorsake binne die gemeenskap waarbinne die Matteusevangelie ontstaan het, kan daaruit vertolk word.

Matteus benoem die nuut totstandgekome Christelike gemeenskap as die kerk (ekkl hs ia), 'n woord wat hy by twee geleenthede in die Evangelie gebruik. Matteus beskryf egter nie 'n hoogs ontwikkelde ekklesiologiese organisasie soos wat in die pastorale briewe en die corpus Paulinum voorkom nie. Sommige verklaarders maak die fout

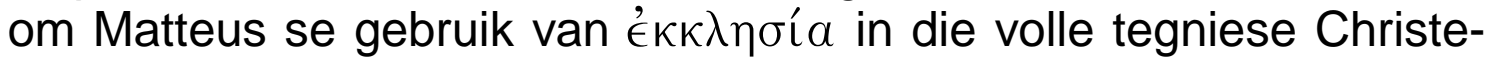
like betekenis (soos wat dit deur die loop van die kerkgeskiedenis ontwikkel het) te interpreteer. Matteus se bedoeling met die woord moet egter deur sy direkte literêre en sosiale konteks bepaal word. Uit hierdie kontekste blyk dit dat Matteus nie formele strukture in gedagte het soos wat die woord "ekklesiasties" deesdae verstaan word nie (Saldarini, 1994:91). Bornkamm (1963:38) merk tereg op dat "only the most meagre beginnings of a real ecclesiology centred in the church as an independent, empirically circumscribed entity, are to be found in Matthew's Gospel". 
'n Belangrike aanduiding van wat Matteus met die kerk bedoel, blyk uit die konflik en skeiding in sy vertellyn (Viljoen, 2006b:245). Sy verhaal bestaan uit 'n proloog en vyf hoofdele waarin die toenemende konflik tussen Jesus en Israel verhaal word (Luz, 2005:244). Die proloog (Matt. 1:1-4:22) antisipeer hierdie afskeiding deur Jesus se reis vanaf die koningstad Bethlehem na Galilea van die heidene (Matt. 4:14-16). Die eerste hoofdeel (Matt. 4:23-11:30) vertel van die verkondiging en genesings deur Israel se Messias onder sy mense. Dit loop uit op 'n dubbelslot wat die skeiding beskryf tussen die onbekeerde Israel en die "kindertjies" aan wie die Seun die Vader bekendmaak (Matt. 11:20-24 en 11:25-30). Die tweede deel (Matt. 12:1-16:20) verhaal 'n reeks episodes waarin Jesus en sy dissipels hulle onttrek van die toenemende vyandskap vanaf die leiers van Israel (Matt. 12:15; 14:13; 15:21; 16:4). Die gemeenskap van Jesus se dissipels kom te voorskyn. Hierdie hoofdeel eindig met Petrus se verklaring en die bou van die kerk (ekkl hsia) (Matt. 16:13-20). Die derde hoofdeel beskryf ' $n$ vredige tussenspel in die lewe van Jesus en die totstandkoming van die kerk. Hierdie gebeure skets die gemeenskap wat uit Jesus se dissipels bestaan (Matt. 16:21-20:34). Daarna volg ' $n$ afdeling oor die finale oordeel oor Israel (Matt. 2125). $\mathrm{Na}$ ' $\mathrm{n}$ inleiding, konfronteer Jesus die godsdienste leiers met drie gelykenisse (Matt. 21:28-22:14), raak betrokke by 'n twisgesprek met Joodse groepe (Matt. 22:15-46), en eindig met die skerp "ellende wag"-rede (Matt. 23). Jesus verlaat die tempel (Matt. 24:12) en berei sy volgelinge vir die oordeelsdag voor (Matt. 24:3-25:46). Lydings- en Paasnarratiewe bring die Evangelie tot 'n konklusie (Matt. 26-28). "The story of Jesus' resurrection (28:1-10) is a story of death for Israel and its leaders." (Luz, 2005:245.) Hulle herken nie die waarheid van Jesus se opstanding nie (Matt. 28:11-15). Hierdie negatiewe einde word gebalanseer deur 'n positiewe ontwikkeling. Jesus gee aan sy dissipels opdrag om dissipels van alle nasies te maak en beloof om tot die voleinding met hulle te wees (Matt. 28:1620). Hierdie dubbele einde lei tot die hopelose toestand van daardie Jode wat Jesus nie erken nie en nie begrip het vir die nuwe sending van die dissipels nie. Op die tweede vlak reflekteer hierdie verhaal die kontemporêre situasie van die Matteusgemeenskap. Hulle het hulle van die nie-Christelike Jode afgeskei en is besig om hulleself buite die sinagoge te organiseer. 2 Die toekomstige sending van die dissipels sluit al die nasies in. Die opgestane Here bly by die gemeenskap wat na die heidene toe uitgestuur word.

2 Die dissipels met wie die geïmpliseerde gehoor van Matteus hulle indentifiseer, bevind hulleself buite die sinagoges (Matt. 4:23; 9:35; 10:17; ens.). 
Matteus beskou die kerk as die ware oorblyfsel van Israel. Op grond van die vervullingsitaat uit Hosea 11:1: "Uit Egipte het Ek my Seun geroep" (Matt. 2:15) blyk dat Matteus die nuwe volk van God parallel beskou aan Israel wat uit Egipte verlos is (France, 1998:207). Jesus word as korporatiewe figuur voorgehou:

The Messiah is not only founder and leader of the Israel-to-be, the new people of God; he is its 'inclusive representative'. In a real sense he is the true Israel, carrying through in his own experience the process through which it comes into being. (Dodd, 1979:106.)

Die mense wat Jesus volg, vorm 'n nuwe gemeenskap van die herstelde volk van God en die kontinuering van Israel (Versteeg, 1980:27). 3 Matteus noem hierdie nuwe gemeenskap die ekkI hs i (Matt. 16:18 and 18:17). In die LXX word die woord algemeen gebruik vir die vertaling van die Hebreeuse woord qahal, die vergadering van die volk van God (bv. Deut. 31:30). Daarbenewens is die woord sunagwghv ook dikwels gebruik as vertaling van qahal (Keener, 1999:428). Deur sy gebruik van hierdie emotiewe konsep uit die Ou Testament en dit onderskeidend as ekkl hs ia te vertaal, wil Matteus klaarblyklik aantoon dat die kerk die rol van die OuTestamentiese volk van God oorgeneem het. Hy onderskei hierdie groep van die sinagoge en sy leiers (Luz, 2001:358). Die beskrywing van die kerk as die ware oorblyfself van Israel werp uiteraard 'n skadu oor die res van Israel. Matteus stel die mislukkings van Israel en hulle oordeel in skerp taal (bv. Matt. 11:16; 12:39-45: 16:4; 17:17). Hy skryf dat "hierdie geslag" skuldig staan en ryp is vir die oordeel. Die skerpste polemiek staan in hoofstuk 23 met sy sewe ellende-spreuke wat afsluit met die strafwaardigheid van "hierdie geslag".

Uit die tweede vlak van Matteus se vertellyn blyk dat een of ander Fariseïstiese groepering meegeding het om die gesag oor en invloed op die populêre idees in die gemeenskap waarbinne die Evangelie geskryf is (Saldarini, 1994:44). Matteus laat blyk dat die Fariseërs nie veronderstel is om die leiers en verteenwoordigers van die godsdienstige gemeenskap te wees nie (Repschinski, 2000:63 e.v.). Matteus verskerp Markus se verwysings na die Joodse leiers se rol in die teenstand en moord van Jesus. Uniek aan Matteus is sy

$3 \quad$ Hierdie afskeiding moet in verband met Matteus 21:43 gelees word: “... die koninkryk van God sal van julle weggeneem word en aan 'n volk gegee word wat die vrugte daarvan sal lewer". 
beskrywing van die Skrifgeleerdes en Fariseërs as "blinde leiers" en "blinde dwase" (Matt. 23:16, 17, 19, 24, 26; 15:14). Matteus identifiseer die Joodse leiers as Jesus se opponente met die skares as toeskouers van hierdie konflik. Jesus is onteenseglik elke keer die oorwinnaar in hierdie stryd.

Matthew intends the audience of the controversy stories to reflect a group that turns from the fraudulent leadership of the opponents of Jesus towards an acknowledgement of the Matthean community as the rightful leaders of Israel. (Repschinski, 2000:329.)

Jesus vervang die "bouers" wat Hom verwerp het, met lojale dissipels (Ps. 118:22; Matt. 21:42-43). Die uitspraak dat Jesus "op hierdie rots"4 (Matt. 16:18) sy kerk sal bou, herinner aan die beeld in 2 Samuel 7 waar die volk van God as 'n tempel uitgebeeld word. Volgens Joodse tradisie is die rots aan die voet van die tempel op die berg Sion ${ }^{5}$ die sentrum van die wêreld. Dit verbind die hemel en Hades, aangesien dit die poort na die hemel is en die portaal na Hades. 6 Indien hierdie uitspraak in die lig van die destydse Joodse tradisies geïnterpreteer word, staan die nuutgevormde ek $\mathrm{kl}$ hs i $\mathrm{a}$ in die sentrum van die wêreld, en is bo die magte van die bose gevestig (Davies \& Allison, 2004:26; Luz, 2005:363). 'n Verwysing na Jesaja 28:15-177 is herkenbaar in hierdie uitspraak van Jesus. Die hoeksteen op Sion sal die aanslag van die storms kan weerstaan, terwyl diegene wat ' $n$ verstandhouding met die doderyk het, deur die bose meegesleur sal word.

4 Waarna hierdie rots verwys, het al tot talle debatte gelei. Die rots is onderskeidend geïdentifiseer met Petrus (volgens die Rooms-Katolieke tradisie), naamlik Petrus se geloof, sy belydenis, sy prediking, die waarheid wat aan hom geopenbaar is, die twaalf apostels, Jesus, Jesus se onderrig, en selfs met God self (Davies \& Allison, 2004:267).

5 Die bergmotief vorm 'n sentrale tema in die verhaal van Matteus (vgl. Donaldson, 1985).

6 In Matteus 16:18 word in dié verband melding gemaak van die "poorte van die doderyk" wat die kerk nie sal oorweldig nie.

7 “Julle sê: 'Ons het 'n ooreenkoms met die dood, ons het 'n verstandhouding met die doderyk; wanneer die vloed aangestroom kom, sal hy ons nie tref nie. Ons het die leuen ons skuilplek gemaak, ons kruip veilig weg agter die valsheid.' So sê die Here my God: Ek gaan in Sion 'n klip neersit, 'n uitgesoekte klip, 'n hoekklip wat fondament aan fondament sal sluit. Wie op My vertrou hoef nie te vlug nie. Ek maak geregtigheid die maatstaf, regverdigheid die toets. Die hael sal julle skuilplek van leuens uitwis, die water sal julle wegkruipplek wegspoel ..." ( Jes. 28:15-19). 
Die Matteusgemeenskap het begin om as kerk hulle eie strukture onderskeidend van die sinagoges tot stand te bring (Mohrlang, 1984:131). Die uitdrukking "the parting of the ways" soos deur Dunn (1980; 1991) gebruik en deur Stanton (1992:99-116) gepopulariseer is, kenmerk hierdie skeiding. Die Matteusgemeenskap het hulle van die sinagoges afgeskei. Hulle moes kies tussen hulle Joodse broers en susters, vaders en moeders, kinders en grond en, aan die ander kant, die Jesus-gemeenskap (Matt. 19:29). Die Jesus-volgelinge sou lojaal wees aan die nuwe gemeenskap wat dissonansie met hulle vorige gemeenskap tot gevolg sou hê (White, 1991:216). Bornkamm (1963:40) verduidelik hoe die kerk hulle van die Judaïsme van die sinagoge onderskei het: "no longer Temple and sacrifices, ritual laws and circumcision (the latter is not once mentioned in Matthew's gospel), nor the rabbinical teaching of the synagogue, but neither a new cultic or hierarchical order; rather discipleship" het die identiteit en merktekens van die nuwe gemeenskap gevorm.

Spanning tussen die kerk en sinagoge het verhoog aangesien die kerk nie-Jode in die Christelike gemeenskap opgeneem het (Luz, 1990:84; Repschinski, 2000:27). In 'n Hellenistiese kultuur binne die Romeinse Ryk het die Jode geworstel om hulle eie identiteit te handhaaf. Dit het tot 'n sterk neiging tot eksklusiwiteit gelei wat spesifiek na vore gekom het in die sinagogale gemeenskap. Matteus bepleit hierteenoor die sending na al die nasies (Matt. 28:18-20).

Die Matteusteks openbaar verset teen die gesag van die Joodse leiers en woordvoerders van die sinagoges. Godsdienstige en politieke gesag en mag was destyds aan mekaar verwant. Die leiers van die sinagoge het die Christengemeenskap uit die sinagoges verban, soos verwoord is in die Birkat ha minim van die Shemoneh 'Esreh wat daagliks in die sinagoge gesiteer is ("Let Nazarenes (Christians) and minim (heretics) perish in a moment, let them be blotted out of the book of the living, and let them not be written with the righteous" (vertaling van France, 1998:85)). Die Birkat ha minim (AD 85) het 'n dekade of wat na die finalisering van Matteusevangelie onstaan en verwoord iets van hierdie spanning wat toe reeds bestaan het (Horbury, 1982:20). Die leiers van die sinagoge het hulleself as sleuteldraers beskou wat Joodse Christene uit hulle vergaderings kon weer. Op die tweede vlak van die verhaal sinspeel Matteus 23:13 moontlik op sodanige optrede: "Ellende wag vir julle, Skriflgeleerdes en Fariseërs, huigelaars! Julle sluit die deur van die koninkryk in die mense se gesig toe. Julle gaan self nie in nie, en julle verhinder dié wat wel wil ingaan" (cf. Allison, 2004:270). Hierteenoor argumenteer Matteus dat die sleutels van die koninkryk 
van die hemele aan die leiers van die kerk toevertrou is. Terwyl die Joodse leiers daarop aanspraak gemaak het dat hulle die sinagoge van Israel kan lei, dring Matteus daarom aan dat die Christelike voorgangers die gesag het om die ekklhsia ooreenkomstig die lerings van Jesus te lei. Die uitsprake van Matteus 16:198 en 18:189 dui daarop dat Petrus en die gemeenskap besondere gesag het. Die eerste uitspraak verwys na die gesag van Petrus, terwyl die tweede na die korporatiewe verantwoordelikheid van die nuwe geloofsgemeenskap verwys. Die sleutels is egter nie dié van 'n aardse organisasie nie, maar van die Koninkryk van die hemel.

Die vraag ontstaan of die kerklike gesagsdraers dan as onfeilbaar beskou is. Twee oorwegings dui op die teendeel (France, 1989: 250). In die eerste plek beklemtoon Matteus herhaaldelik die feilbaarheid van Petrus en die dissipels - dieselfde dissipels waaruit die ekkl hs i a bestaan. In die tweede plek behoort die ekkl hs i a nie aan Petrus nie, maar aan Jesus. Die gesag van die kerk is in Jesus geleë. Jesus beskik finaal oor die gesag, maar Hy delegeer dit op 'n bepaalde manier aan sy verteenwoordigers op aarde. Die bewoording van Matteus 16:19 en 18:18 dui daarop dat die frases oorspronklik onafhanklik van die Matteuskonteks ontstaan het. Jesaja 22:2210 toon die nouste Ou-Testamentiese ooreenkoms met die metafoor van die sleutels en dien mees waarskynlik as agtergrond van die uitspraak (Davies \& Allison, 2004:265). Matteus 16:19 beskryf die eskatologiese vervulling van die beloftes wat aan die huis van Dawid gemaak is. Dit blyk ook dat die gesag van Petrus en die kerk nie soseer as deurwagters geld nie, maar as dienaars. Die gesag om te kan oop- of toesluit moet in die lig van die rabbynse gebruik van dié woorde geïnterpreteer word. Die rabbyne het oopen toegesluit ooreenkomstig dit wat deur die wet verbied of gebied word (cf. Derrett, 1983:112-117). Hierdie terme verwys daarom na die lerende funksie van dienaars wat halakha-uitsprake maak wat

8 Matteus 16:19: "Ek sal aan jou die sleutels van die koninkryk van die hemel gee, en wat jy op die aarde toesluit, sal in die hemel toegesluit by; en wat jy op die aarde oopsluit, sal in die hemel oopgesluit bly."

$9 \quad$ Matteus 18:18: "Dit verseker Ek julle: Wat julle ook al op die aarde toesluit, sal in die hemel toegesluit bly; en wat julle ook al op die aarde oopsluit, sal in die hemel oopgesluit bly."

10 Jesaja 22:20-22: "Dan sal Ek my dienaar Eljakim seun van Gilkija roep ... Ek sal jou ampskleed vir hom aantrek, ... en die gesag wat jy nou het vir hom gee. Aan hom sal Ek die sleutels van die koning se huis gee; wat hý oopsluit sal niemand toesluit nie, wat hý toesluit, sal niemand oopsluit nie." 
bindend is vir die volk van God. Die gesag van hierdie uitsprake is daarin geleë dat dit die besluite oordra wat reeds in die hemel geneem is. In Matteus 16:18 beloof Jesus dat Hy sy ekkl hs i op Simon, wat ook "rots" genoem word, sal bou. Hierdie metafoor dui op stabiliteit en duursaamheid van die Christelike gemeenskap (Crosby, 1988:52). Die gesag van die gemeente (al is dit hoe klein en bedreig) is geleë in die hantering van die sleutels van die hemelryk. Jesus en God is in hulle midde en hulle toekoms is verseker onder God se heerskappy (Matt. 16:16). Matteus 18:17 dui op die samekoms van die lede van die gemeenskap. Hierdie gemeenskap probeer om 'n lid van die gemeenskap te dissiplineer en hulle gesag daartoe word deur God erken (Matt. 18:18-19). Hoewel hierdie kerk nog nie in 'n hoë mate geïnstitutionaliseer is nie, dra dit reeds gesag, omdat God teenwoordig is waar twee of drie in sy Naam vergader is (s unhgmenoi - etimologies verwant aan die woord sinagoge).

Die kerk skep 'n omgewing waarbinne daar met reg opgetree moet word. In Matteus 18 word onder andere gewaarsku teen die verskriklike gevaar om "een van die kleintjies" wat in Jesus glo, van Hom afvallig te maak (Matt. 18:6 e.v.). Hierbenewens blyk die onderlinge ondersteuning van die gemeenskap deur die manier waarop hulle moet optree teenoor een lid wat teen 'n ander sondig (Matt. 18:15-17).

\section{Reg in Matteus}

Die år cos (heilig)-woordgroep is nie prominent in Matteus nie. Die

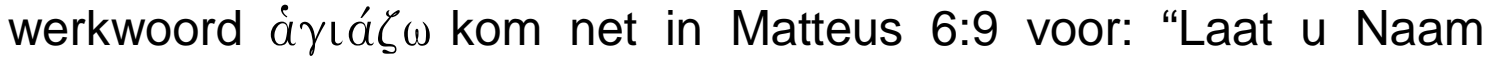
geheilig word", en in Matteus 23:17 en 19 waar dit na die goud van die tempel verwys. Die byvoeglike naamwoord åylos word met "Gees" en die "Stad" gebruik, en een keer met "plek" (Matt. 24:15). Matteus se woord vir die lewenstyl van gelowiges is egter

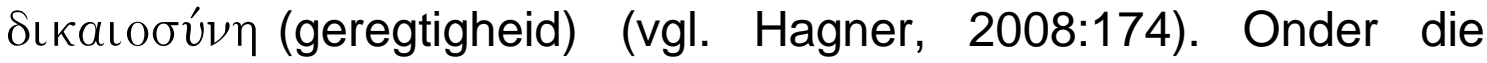
Sinoptiese Evangelies kom die woord net in Matteus voor, met die uitsondering van die verwysing na Sagaria se profesie in Lukas 1:75.

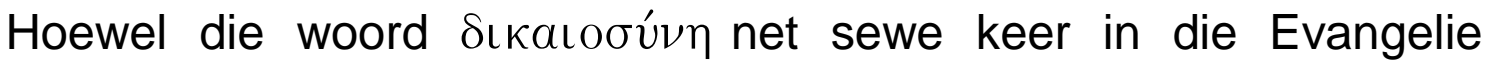
volgens Matteus voorkom, vertolk dit op 'n besondere manier Matteus se beskouing oor die lewe van Jesus en die geloofsgemeen-

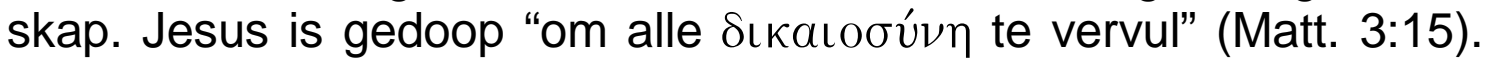
Die woord kom vyf keer in die Bergrede voor. Die bevoordeeldes

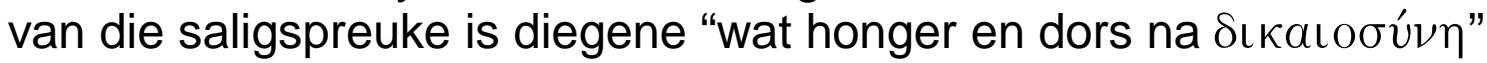




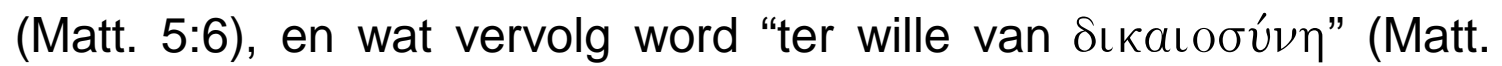

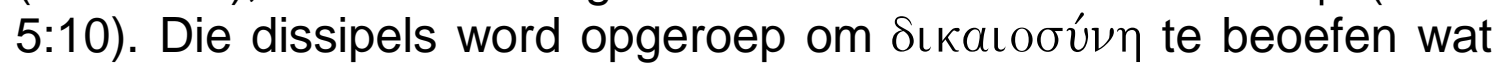
oorvloediger is as dié van die Fariseërs en die Skrifgeleerdes (Matt.

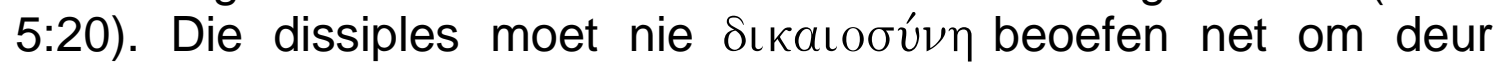
mense gesien te word nie (Matt. 6:1). Hulle moet hulle allereers

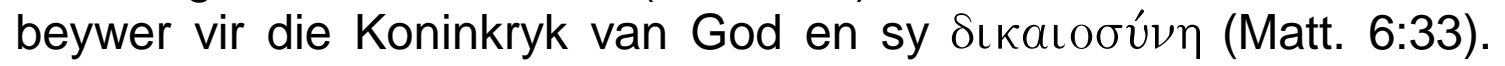

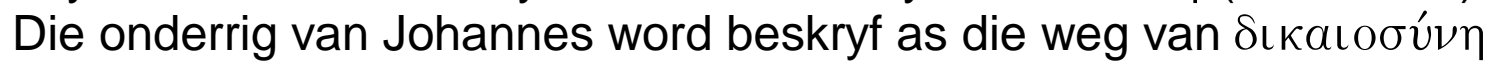
(Matt. 21:32). Geregtigheid vorm 'n sleutelterm in die Bergrede vanaf die saligspreuke tot met die klimaktiese oproep in Matteus 6:33. Gelees saam met die optrede van Johannes die Doper (Matt. 3:15 en 21:35) vorm die eerste en laaste verwysings na $\delta \iota к а \iota о б u ́ v \eta$ in die Evangelie 'n inclusio rondom die vyf verwysings daarna in die Bergrede (Deines, 2008:80). Matteus gebruik $\delta \iota \kappa a \iota$ бúv $\eta$ as ' $n$ besonder gelade begrip, veral in die Bergrede.

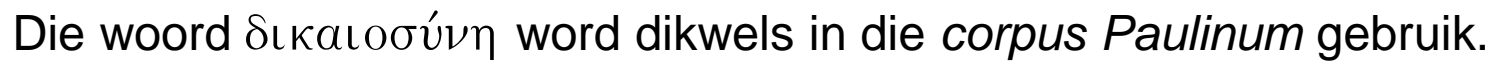
Die onversigtige leser kan maklik die fout maak om Matteus se gebruik van die woord in die lig van die oorvloedige gebruik deur Paulus te interpreteer. 'n Noukeuriger lees van die woord het daartoe gelei dat navorsers besin het oor die verhouding tussen Matteus en Paulus se gebruik van die woord. Uit hierdie navorsing blyk dit dat Paulus die woord hoofsaaklik in forensies-soteriologiese sin en

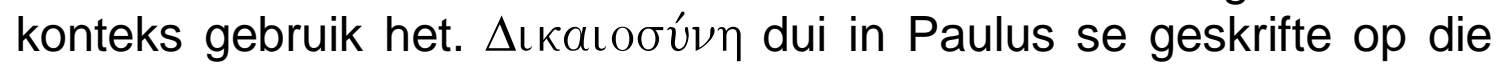
verlossing wat God in Christus bewerk het. Matteus heg ander konnotasies aan die woord. Matteus gebruik die woord hoofsaaklik om menslike optrede in etiese terme te beskryf (Strecker, 1971: 187). Vir Matteus is dit 'n etiese konsep wat "thoroughgoing and determined obedience to the deepest intent of the law" (Mohrlang, 1984:113) behels. Paulus en Matteus se gebruike van die woord is duidelik te onderskei. Dit is daarom belangrik om die betekenis van

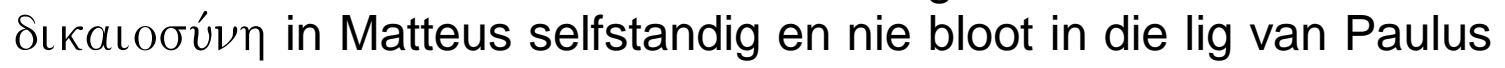
se gebruik van die woord te interpreteer nie.

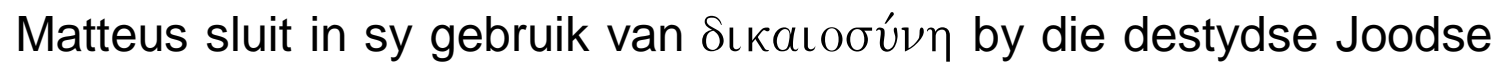
gebruik van die woord aan. Przybylski (1980:13 e.v.) toon aan dat

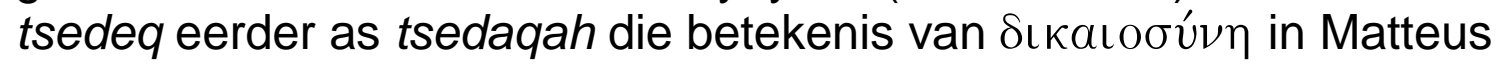
vertolk. Tsedaqah denoteer soteriologie as 'n gawe van God, terwyl tsedeq op die norm dui waarvolgens 'n persoon se optrede voor God beoordeel word. Tsedeq verwys na die optrede van 'n mens wat volgens die wil van God lewe. God se wil is in die Torah opgeteken. Die korrekte interpretasie van die Torah was 'n vraagstuk wat gelei het tot ernstige twisgesprekke tussen Skrifgeleerdes en skismas in die Judaïsme (Viljoen, 2006a:136). Matteus berig ook van heftige twisgesprekke tussen Jesus en Skrifgeleerdes van sy tyd. 
Die rol van die Torah en die Skrifgeleerdes se leringe wat daarop gebaseer is, vorm 'n prominente tema in Matteus. Reeds in die sestiende eeu het Sebastian Münster die inhoud van Matteus as 'n "nuwe Torah" getipeer (Lapide, 1985:55). Die onderlinge stryd oor die betekenis van die Torah het nie ontstaan omdat die verskillende groepe die belangrikheid daarvan ontken het nie, inteendeel. Dit was juis hulle strewe om die spesifieke implikasies van die Torah te verstaan wat tot twisgesprekke gelei het oor wat die Torah in die praktyk sou beteken. Elke groep wou daarop aanspraak maak dat hulle die beginsels van die Torah reg verstaan en in die praktyk die beste uitleef. Dit het geïmpliseer dat die ander groepe dit minder goed of verkeerd gedoen het. "In such polemic the need for a group to find in the Torah its own self-affirmation had the inevitable corollary of making the Torah an instrument by means of which one group condemned another" (Dunn 2003:292). Te midde van die destydse wedywering oor wat die Torah in die praktyk impliseer, dui $\delta \iota \kappa a \iota$ $v ́ \nu \eta$ in Matteus op die manier waarop die Torah uitgeleef moet word in ooreenstemming met die gesagvolle interpretasie daarvan deur Jesus.

Volgens die evangelis is dit in die eerste plek Jesus wat alle

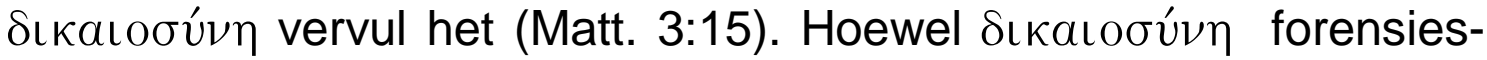
soteriologies of eties geïnterpreteer kan word, blyk 'n etiese interpretasie hier meer gepas. Deurdat hulle die Skrifte vervul, tree Johannes en Jesus reg op (Allison, 2004:46; Deines, 2008:81). Jesus aanvaar die wil van God en gehoorsaam dit gewillig. Hy was 'n regverdige mens, selfs buitestanders het dit besef (Matt. 10:41; 23:34-36; 27:4, 19, 24-26). Volgens Joodse verwagtings sou dit die

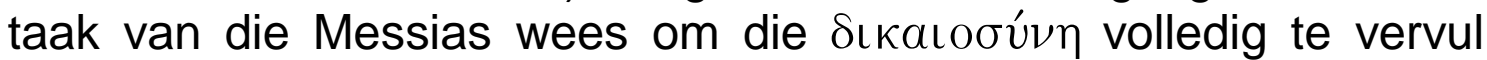
(Davies \& Allison, 2004:325). Aangesien Jesus die messiaanse profesieë van die Joodse Bybel geken het, het Hy dit gehoorsaam

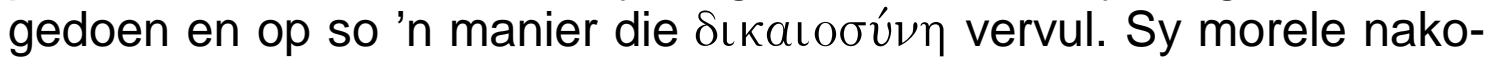
ming van die wil van God staan voorop.

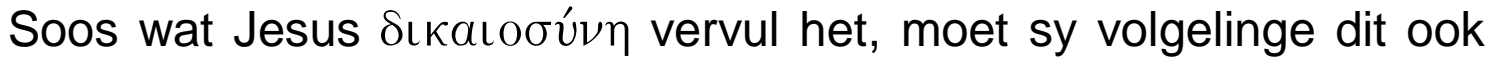

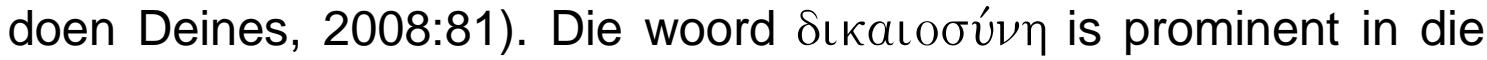
Bergrede (die grondwet van die nuwe geloofsgemeenskap). In hierdie rede word die woord deurgaans binne etiese konteks gebruik (in teenstelling met die Pauliniese forensies-soteriologiese gebruik van die woord, wat 'n eskatologiese implikasie vir regverdiging sou impliseer). In Matteus "[r]ighteousness is to be taken in the Jewish sense as a discipline that the disciple must learn" (Betz, 1995:352). "This does not mean God's eschatological vindication of the saints or divine justice but the conduct God requires" (Allison, 2004:102). In 
die Bergrede dui geregtigheid op die hoogste vorm van ware dissipelskap.

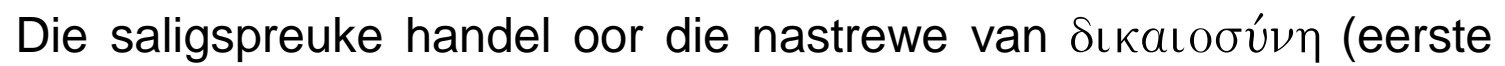

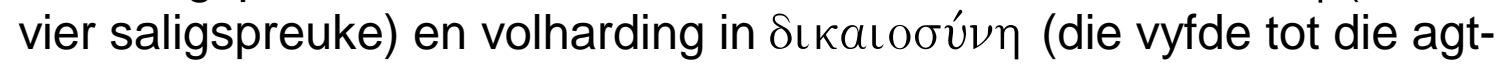
ste saligspreuke) (Viljoen, 2008:210). Wanneer 'n mens die vierde saligspreuk (Matt. 5:6) met sy parallel in die Vlakterede (Luk. 6:21a) vergelyk, kom die bepaalde beklemtoning van Matteus na vore. Terwyl die Vlakterede hoofsaaklik oor fisiese honger handel, stel die Bergrede die spreuk in etiese konteks - die woorde "honger en dors na $\delta$ ıаıобú $\nu$ " is bygevoeg. Terwyl die spreuk in die Vlakterede oor die gevolg van sosiale ongeregtigheid handel, toon die parallele spreuk in die Bergrede aan hoe sodanige ongeregtigheid reggestel kan word (Betz, 1995:129). Die Bergredespreuke onderderskei nie tussen sosiale en persoonlike geregtigheid nie. Albei word veronder-

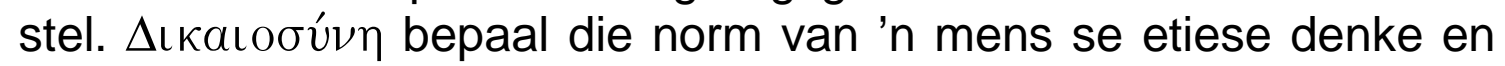

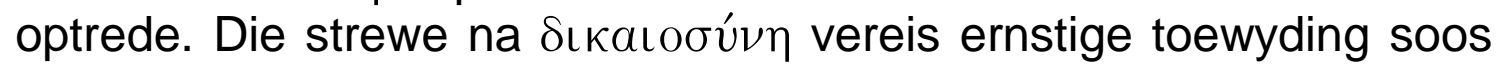
iemand wat daarna honger en dors. Hierdie strewe na $\delta ı к а\llcorner о \sigma u ́ v \eta$ is net moontlik as dit gedoen word op die manier waarop Jesus die Torah interpreteer. Honger en dors na

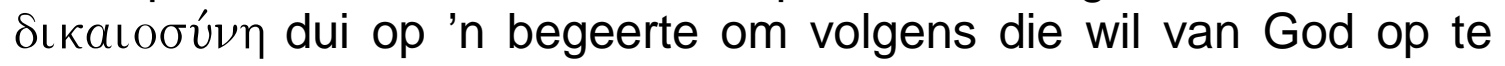
tree, hoewel daar nog tekortkomings mag wees. Die blote begeerte om volgens die wil van God te leef, eis volledige toewyding. Dit is niks anders nie as die liefde vir God, soos verwoord deur Jesus: "Jy moet die Here jou God liefhê met jou hele hart en jou hele siel en met jou hele verstand" (Matt. 22:37). Terwyl 'n hartlike strewe na

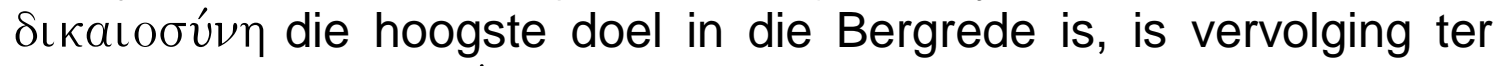

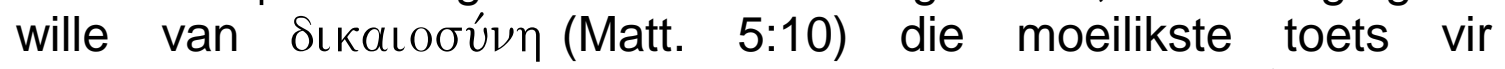

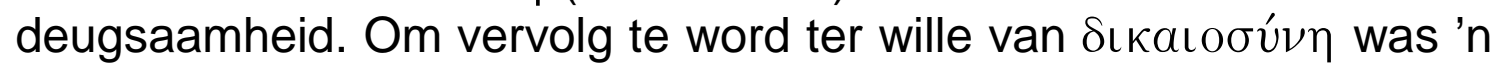
bekende tema in die destydse Judaïsme. "Judaism considered it to be the greatest test for the righteous, the supreme means of divine education" (Betz, 1995:146). Mense wat sodanige geregtigheid beoefen, word beskryf as die "sout van die aarde" (Matt. 5:13) en "die lig vir die wêreld" (Matt. 5:14).

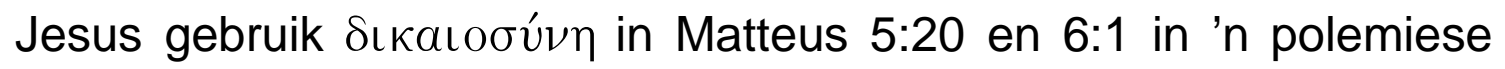
konteks en verwys na etiese optrede wat nie uit skyn gedoen word nie, maar op grond van 'n opregte gesindheid (Viljoen, 2006a:150). Hy kritiseer die uiterlike en kunsmatige godsdienstige optrede van die Fariseërs en Skrifgeleerdes en konstateer dat Hy verwag dat sy dissipels met hulle optrede opreg daarna moet streef om hulle Vader 


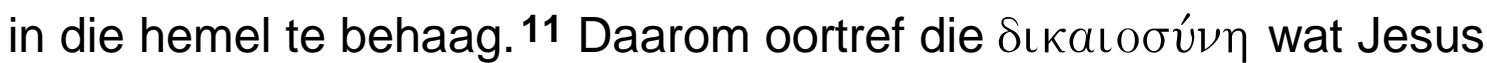
vereis dít wat die Fariseërs en Skrifgeleerdes as geregtigheid beskou. Jesus verklaar emfaties en by herhaling in die vorm van ses antitesisse: "Maar Ek sê vir julle ..." (Matt. 5:22, 28, 32, 34, 39, 44) wat daarop dui dat Hy 'n dieper betekenis in die Torah herken as wat algemeen aanvaar word. "The antitheses should better be called 'instructions about the practice of eschatological righteousness'"

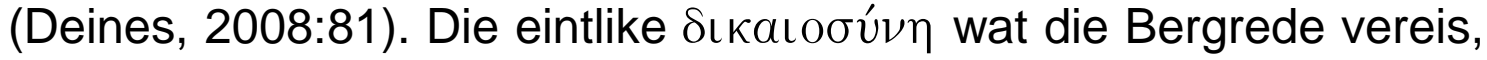
word deur Jesus verduidelik en hou verband met die manier waarop Hy gesagvol (teenoor die ander Skrifgeleerdes) die Torah interpreteer. Die Torah eis niks minder nie as volmaaktheid (Matt. 5:48). Jesus se interpretasie het etiese implikasies met 'n duidelike eska-

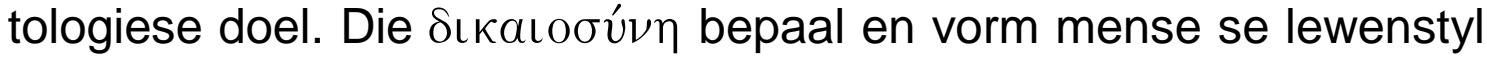
op aarde en berei hulle voor om die Koninkryk van die hemel in te gaan.

Die telos-formule 12 van die die Bergrede (Matt. 6:33) beklemtoon

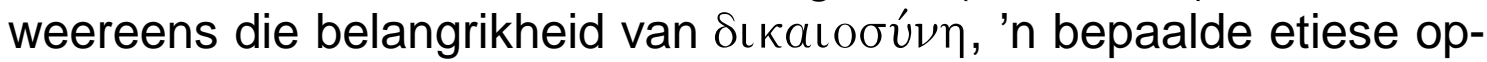
trede as volgeling van Jesus (Allison, 2004:102). Om jou vir die

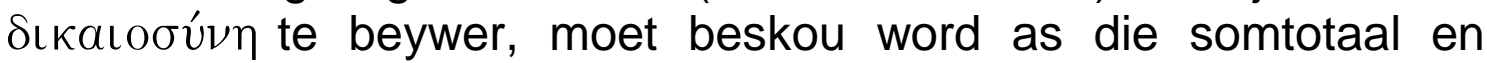
hoogste waarde van dissipelskap.

In Matteus 21:32 redeneer Jesus dat Johannes 'n onberispelike en vroom profeet was. Hy het na die Jode gekom in die weg van

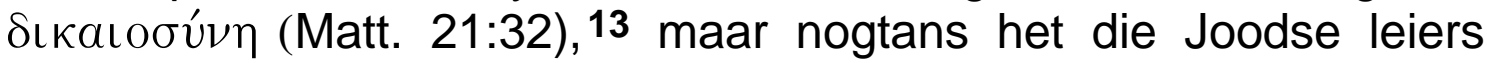

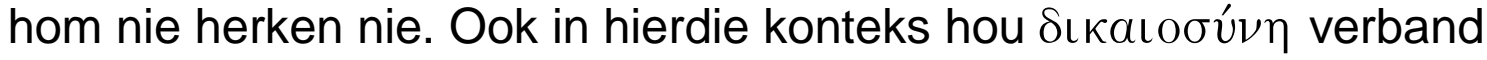
met die etiese optrede (Van Bruggen, 1990:383). Sowel hier as in Matteus 3:15 word gestel dat Johannes die Doper (soos Jesus) 'n voorbeeld is van regverdige optrede, as morele model.

Dit is hierdie vorm van geregtigheid waarna Jesus in sy sendingopdrag verwys: "... en leer hulle om alles te onderhou wat Ek julle beveel het" (Matt. 28:20).

11 Hierdie uitspraak herinner aan 1 Samuel 16:7: "Die mens kyk na die uiterlike, maar die Here na die innerlike."

12 Griekse filosowe het telos-stellings geformuleer om die doel van hulle etiek te definieer (Betz, 1995:481).

13 Ook in Matteus 22:16 word hierdie bekende Joodse uitdrukking "weg van geregtigheid" in 'n etiese sin gebruik. 


\section{Konklusie}

Deur Jesus het die Koninkryk van God gekom. Hierdie keerpunt in die geskiedenis het daartoe gelei dat 'n nuwe volk van God tot stand gekom het. Matteus roep hierdie gemeenskap tot geregtigheid op.

Die Matteusgemeenskap het begin om afsonderlik van die sinagoges hulle eie strukture te vorm. Onderskeidend van die s unagwghy noem Jesus in Matteus hierdie nuwe gemeenskap die ekkl hs i 1 . Op grond van hulle toewyding aan Jesus as verhoogde en apokaliptiese figuur beoog die Matteusgemeente om die Joodse gemeenskap te hervorm. Hulle lewenstyl en die manier waarop hulle die wil van God interpreteer, moet deur hierdie toewyding bepaal word. Volgens Matteus is die kerk die ware en getroue oorblyfsel van Israel. Die ekkl hs i in Matteus verwys nog nie na die volledig ontwikkelde korporatiewe organisasie soos wat in die pastorale geskrifte en Corpus Paulinum beskryf word nie. Nogtans is die ekkl hsia nie bloot 'n menslike organisasie wat die sosiale orde probeer beïnvloed nie. Die ekkl hs i o ontvang sy gesag en bepalings deur Jesus van God af. Nie-Jode is by die kerk geïnkorporeer, 'n ontwikkeling wat heelwat spanning met die Judaïstiese bewegings tot gevolg gehad het. Die Matteus-teks openbaar verset teen die gesag van die Joodse leiers en woordvoerders van die sinagoges. Matteus argumenteer dat die sleutels van die Koninkryk van die hemel aan die kerk en sy leiers gedelegeer is. Die poorte van die doderyk sal die kerk nie oorweldig nie, anders as wat dit met die teenstanders van Jesus die geval sal wees. Polemiese argumente teen die sinagoge het ' $n$ belangrike rol gespeel in die selfdefiniering van die Christengemeenskap te midde van die krisis van afskeiding en transisie.

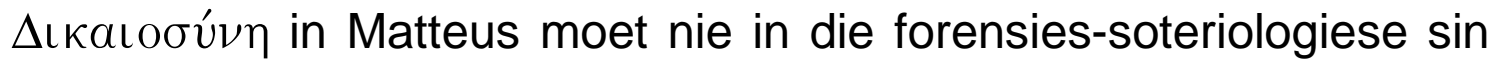
van die woord verstaan word, soos in die geval van Paulus se ge-

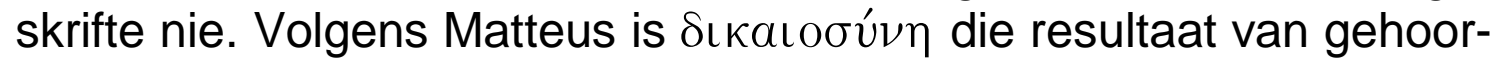
saamheid aan die wil van God soos geopenbaar in die Torah. Jesus het die dieper implikasies van die Torah ingesien en dit gesagvol aan sy volgelinge geleer. Jesus se unieke en gesagvolle interpretasie van die Torah verklaar die dieper dimensie en praktiese uitlewing van die bepalings daarvan. Johannes die Doper en Jesus in die besonder, dien as voorbeelde van mense wat die wil van God uitgevoer het. Soortgelyke getroue uitlewing van die wil van God word van sy kerk verwag. Op 'n besondere manier voorsien God die

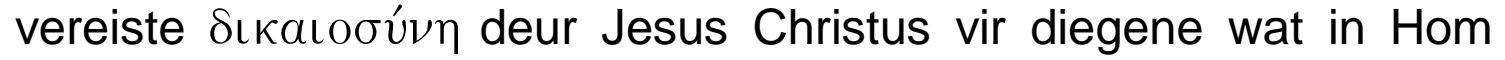
glo. Matteus glo wel dat verlossing 'n gawe van God is, maar hierdie gawe kom die dissipels van Jesus toe. Ware dissipelskap word gedemonstreer in die nakoming van die wil van God. Om die wil van 
God uit te leef op die manier waarop Jesus dit geleer het, is die onderskeidende kenmerk van die geloofsgemeenskap wat die kerk genoem word.

As transparante verhaal berig Matteus in die eerste plek van die unieke gemeenskap van die eerste dissipels wat hulle as geloofsgemeenskap rondom Jesus geskaar het en op 'n bepaalde manier hulle lojaliteit teenoor Hom uitgeleef het. Tog het die manier waarop Jesus die eerste geloofsgemeenskap rondom Hom vergader en georganiseer het, implikasies vir die kerk waarbinne Matteus geskryf is en vir die kerk deur die eeue. Die kerk, die nuwe gemeenskap van gelowiges wat deur Jesus geskep is, bring 'n omgewing tot stand waar geregtigheid tot uitdrukking moet kom. Hierdie gemeenskap word opgeroep tot volkome toewyding aan Jesus Christus, gehoorsaamheid aan sy woorde en onderwerping aan sy heerskappy, wat dit ook al mag kos. Jesus roep die kerk tot persoonlike en sosiale geregtigheid wat 'n positiewe verskil maak. Sodanige geregtigheid stel verkeerdhede reg en bou 'n gemeenskap op. Kerklike geregtigheid hou meer in as blote woorde en uiterlike skyn van vroomheid. Dit is veel meer as die formele nakoming van uiterlike regulasies. Kerklike geregtigheid word gemotiveer deur 'n hart wat deur Jesus Christus volkome aan God toegewy is.

Die opdrag wat Matteus aan die kerk gee om volmaakte geregtigheid uit te leef, lyk menslik hopeloos onbereikbaar. Maar dan klink die bemoedigende woorde uit dieselfde Evangelie: "Vir mense is dit onmoontlik, maar vir God is alles moontlik" (Matt. 19:26). Van die kerk word verwag om volmaakte geregtigheid as uiteindelike doel na te streef. So bou Christus sy kerk.

Du Plooy se ideaal dat kerkreg nie geleë moet wees in die uiterlike nakoming van regulasies nie, maar die opbou van die kerk van Christus moet dien, eggo die prediking van Matteus in hierdie verband.

\section{Geraadpleegde bronne}

ALLISON, D.C. 2004. Matthew: a shorter commentary. London: Clark.

BAUCKHAM, R. 1998. The gospels for all Christians: rethinking the gospel audiences. Grand Rapids: Eerdmans.

BETZ, H.D. 1995. The Sermon on the mount: a commentary on the Sermon on the mount, including the sermon on the plain. Minneapolis: Fortress.

BORNKAMM, G. 1963. End-expectation and church in Matthew. (In Bornkamm, G., Barth, G. \& Held, H-J., eds. Tradition and interpretation in Matthew. Philadelphia: Westminster. p. 26-51.) 
CARTER, W. 2000. Matthew and the margins: a socio-political and religious reading. Sheffield: Sheffield Academic Press. (Journal for the Study of the New Testament Supplement Series, 204.)

CROSBY, M.H. 1988. House of disciples: church, economics and justice in Matthew. New York: Orbis.

DAVIES, W.D. \& ALLISON, D.C. 2004. Matthew 1-7: international critical commentary. London: Clark.

DEINES, R. 2008. Not the law but the Messiah: law and righteousness in the Gospel of Matthew - an ongoing debate. (In Gurtner, D.M. \& Nolland, J., eds. Built upon the rock: studies in the Gospel of Matthew. Grand Rapids: Eerdmans. p. 53-84.)

DERRET, J.D.M. 1983. Binding and loosing (Matt. 16:19; 18:18; John 20:23). Journal of Biblical literature, 102:112-117.

DODD, C.H. 1979. The founder of Christianity. London: Collins.

DONALDSON, T.L. 1985. Jesus on the mountain: a study in Matthean theology. Sheffield: JSOT.

DU PLOOY, A. le R. 1995. Die grondslag en relevansie van die gereformeerde kerkreg as teologiese wetenskap. In die Skriflig, 29(1 \& 2):135-160.

DU PLOOY, A. le R. 1998. The keys of the kingdom as paradigm of building up the church in reformed church government. In die Skriflig, 32(1):53-68.

DUNN, D.G. 1980. Christology in the making. London: Westminster.

DUNN, D.G. 1991. The parting of the ways between Christianity and Judaism and their significance for the character of Christianity. Philadelphia: Trinity Press International.

DUNN, J.D.G. 2003. Jesus remembered. Grand Rapids: Eerdmans. (Christianity in the making, 1.)

FRANCE, R.T. 1998. Matthew: evangelist and teacher. Illinois: InterVarsity.

HAGNER, D.A. 2008. Holiness and ecclesiology: the church in Matthew. (In Gurtner, D.M. \& Nolland, J., eds. Built upon the rock: studies in the Gospel of Matthew. Grand Rapids: Eerdmans. p. 170-186.)

HORBURY, W. 1982. The benediction of the minim and early Jewish Christian controversy. Journal of theological studies, 33:19-61.

HUMMEL, R. 1966. Die Auseinandersetzung zwischen Kirche und Judentum im Matthäusevangelium. München: Kaisar.

JOHNSON, L.T. 1986. The writings of the New Testament. Philadelphia: Fortress.

KEENER, G.S. 1999. A commentary on the Gospel of Matthew. Michigan: Eerdmans.

KLIJN, A.F.J. 1968. De wordingsgeschiedenis van het Nieuwe Testament. Utrecht: Het Spectrum NV.

LAPIDE, P. 1985. Jesus in two perspectives: a Jewish-Christain dialog. Minneapolis: Augsburg Publishing House.

LUZ, U. 1990. Matthew 1-7: a commentary. Edinburgh: Clark.

LUZ, U. 2001. Matthew 8-20: a commentary. Minneapolis: Fortress.

LUZ, U. 2005. Studies in Matthew. Grand Rapids: Eerdmans.

MARTIN, J.P. 1975. The church in Matthew. Interpretation, 29(1):41-56.

MOHRLANG, R. 1984. Matthew and Paul: a comparison of ethical perspectives. Cambridge: Cambridge University Press.

PRZYBYLSKI, B. 1980. Righteousness in Matthew and his world of thought. Cambridge: Cambridge University Press. 
OVERMAN, J.A. 1990. Matthew's Gospel and formative Judaism: the social world of the Matthean community. Mineapolis: Fortress.

RADFORD RUETHER, R. 1974. Faith and fratricide: the theological roots of anti-semitism. New York: Seabury.

REPSCHINSKI, B. 2000. The controversy stories in the Gospel of Matthew: their redaction, form and relevance for the relationship between the Matthean community and formative Judaism. Göttingen: Vandenhoeck \& Ruprecht.

SALDARINI, A.J. 1991. The Gospel of Matthew and Jewish-Christian conflict. (In Balch, D.L., ed. Social history of the Matthean community: crossdisciplinary approaches. Minneapolis: Fortress. p. 38-61.)

SALDARINI, A.J. 1994. Matthew's Christian-Jewish community. Chicago: University of Chicago.

STANTON, G.N. 1992. Matthew's Christology and the parting of the ways. (In Dunn, J.D.G., ed. The parting of the ways AD 70 to 135: the second Durham-Tübingen research Symposium on Earliest Christianity and Judaism, Durham, September 1989. Tübingen: Mohr- Siebeck. p. 99-116.) (WUNT, 66.)

STRECKER, G. 1971. Der Weg der Gerechtigkeit: Untersuchung zur Theologie des Matthäus. Göttingen: Vandenhoeck \& Ruprecht.

VERSTEEG, J.P. 1980. Evangelie in viervoud: een karakteristiek van de vier evangeliën. Kampen: Kok.

VILJOEN, F.P. 2006a. Jesus' teaching on the Torah in the Sermon on the Mount. Neotestamentica, 40(1):135-156.

VILJOEN, F.P. 2006b. The Matthean community according to the beginning of his Gospel. Acta theologica, 26(2):242-262.

VILJOEN, F.P. 2007a. Fulfilment in Matthew. Verbum et ecclesia, 28(1):301324.

VILJOEN, F.P. 2007b. Matthew, the church and anti-Semitism. Verbum et ecclesia, 28(2):698-718.

VILJOEN, F.P. 2008. The double call for joy, "Rejoice and be glad" (Matt. 5:12), as conclusion of the Matthean macarisms. Acta theologica, 28(1):205-221.

WHITE, L.M. 1991. Crises management and boundary maintenance: the social location of the Matthean community. (In Balch, D.L., ed. Social history of the Matthean community: cross-disciplinary approaches. Minneapolis: Fortress. p. 210-225.)

\section{Kernbegrippe:}

kerk

kerkreg

Matteus

reg/geregtigheid

\section{Key concepts:}

church

church polity

Matthew

righteousness 
